\title{
Low levels of 3,3'-diindolylmethane activate estrogen receptor $a$ and induce proliferation of breast cancer cells in the absence of estradiol
}

\author{
Maud Marques, Liette Laflamme, Ines Benassou, Coumba Cissokho, Benoit Guillemette and Luc Gaudreau*
}

\begin{abstract}
Background: 3,3'-diindolylmethane (DIM) is an acid-catalyzed dimer of idole-3-carbinol (I3C), a phytochemical found in cruciferous vegetables that include broccoli, Brussels sprouts and cabbage. DIM is an aryl hydrocarbon receptor (AhR) ligand and a potential anticancer agent, namely for the treatment of breast cancer. It is also advertised as a compound that regulates sex hormone homeostasis.
\end{abstract}

Methods: Here we make use of RNA expression assays coupled to Chromatin Immunoprecipitation (ChIP) in breast cancer cell lines to study the effect of DIM on estrogen signaling. We further make use of growth assays, as well as fluorescence-activated cell sorting (FACS) assays, to monitor cell growth.

Results: In this study, we report that 'physiologically obtainable' concentrations of DIM (10 $\mu \mathrm{M})$ activate the estrogen receptor a (ERa) signaling pathway in the human breast cancer cell lines MCF7 and T47D, in a 17ßestradiol (E2)-independent manner. Accordingly, we observe induction of ERa target genes such as GREB1 and TFF1, and an increase in cellular proliferation after treatment with $10 \mu \mathrm{M}$ DIM in the absence of E2. By using an ERa specific inhibitor (ICI 182 780), we confirm that the transcriptional and proliferative effects of DIM treatment are mediated by ERa. We further show that the protein kinase A signaling pathway participates in DIM-mediated activation of ERa. In contrast, higher concentrations of DIM (e.g. $50 \mu \mathrm{M}$ ) have an opposite and expected effect on cells, which is to inhibit proliferation.

Conclusions: We document an unexpected effect of DIM on cell proliferation, which is to stimulate growth by inducing the ERa signaling pathway. Importantly, this proliferative effect of DIM happens with potentially physiological concentrations that can be provided by the diet or by taking caplet supplements.

\section{Background}

Breast cancer is one of the leading causes of death in industrialized countries and estrogens are known to play a role in its promotion [1]. Initiation of breast cancer by $17 \beta$-estradiol (E2) can involve the formation of DNA damage via its oxidation products. Accordingly, E2 is a substrate for the phase I cytochrome P450 (CYP) enzymes, CYP1A1 and CYP1B1. These two enzymes oxidize E2 into 2-hydroxyestradiol (2-OHE2) and 4-hydroxyestradiol (4OHE2), respectively $[2,3]$. The 2-OHE2 metabolites can bind estrogen receptor $\alpha(E R \alpha)$, but do not induce transcriptional activity [4]. On the other hand, 4-OHE2 hydroxylation results in the formation of a carcinogenic

\footnotetext{
* Correspondence: Luc.Gaudreau@USherbrooke.ca

Département de Biologie, Université de Sherbrooke, J1K 2R1 Sherbrooke, QC, Canada
}

\section{Ciomed Central}

metabolite that can be further oxidized to highly reactive semiquinones and quinines [5]. These C-4 metabolites are well characterized and known to produce DNA adducts that lead to depurination of DNA [6-9]. CYP1B1 has been found in high concentrations in many types of tumors compared to normal tissues [10]. These observations suggest a function for CYP1B1 in promoting tumor growth. To support this hypothesis, the expression of CYP1B1 has been observed in mammary tissue many weeks prior to the appearance of tumors in DMBA-treated rats [11]. Furthermore, in normal mammary tissue, 2-OHE2-derived metabolites are the main conversion products of E2, while a significant increase of 4-OHE2-derived metabolites is observed in cancerous mammary tissue. Based on these observations, a model has been put forth wherein the 
CYP1A1/CYP1B1 enzyme ratio is essential to control the intracellular level of genotoxic estrogen metabolites [12].

The $C Y P 1 A 1$ and $C Y P 1 B 1$ genes are expressed primarily in extra-hepatic tissue and are regulated by the aryl hydrocarbon receptor (AhR), a ligand-activated transcription factor that belongs to the bHLH/PAS family. AhR ligands are numerous and belong to several classes of chemicals including halogenated aromatic hydrocarbons (HAH) such as 2,3,7,8-tetrachlorodibenzo-p-dioxin (TCDD), polycyclic aromatic hydrocarbons (PAH) such as benzopyrene, and phytochemicals found in cruciferous vegetables like 3,3' -diindolylmethane (DIM). Female rodents exposed to TCDD for two years showed an increase in liver cancer incidence but a decrease in spontaneous mammary tumor formation [13]. Later studies revealed that TCDD and other AhR ligands inhibit cellular proliferation of human breast cancer cell lines, $[14,15]$ as well as DMBA-induced mammary tumors in rats [16], and, consequently, these observations highlight a possible functional crosstalk between AhR and ER $\alpha$ signaling. The potential role of the AhR signaling pathway in mammary carcinogenesis inhibition led to the development of selective AhR modulators (SAhRMs) that act as potential anticancer agents. Even if TCDD possesses chemopreventive and chemotherapeutic proprieties in breast cancer development, it also induces acute liver toxicity. SAhRMs, like DIM, are reported to have the same inhibitory effects on mammary tumor formation in rats without having the deleterious effects of TCDD and other toxic AhR ligands. DIM is an acidcatalyzed dimer of indol-3-carbonyl (I3C), a compound found in cruciferous vegetables such as broccoli, Brussels sprouts and cabbage. DIM is one of the most biologically active products examined so far [17], and because of its potential chemotherapeutic functions, it has been extensively studied. Reports showed that DIM treatment induces a G1 arrest in the cell cycle of breast, ovarian, prostate, and colon cancer cell lines [18-23]. In addition, DIM also induces apoptosis and $p 21$ expression in a p53independent manner [24-26], and is a low affinity ligand for AhR. However, conflicting reports can be found in the literature as to whether DIM is an agonist or an antagonist of AhR in the expression of the CYP1 family of genes [27-31]. Furthermore, DIM activates ER $\alpha$ in a ligandindependent manner, which involves the protein kinase A (PKA) and mitogen-activated protein kinase (MAPK) signaling pathways under certain conditions [32].

As a natural compound, DIM can easily be taken as a dietary supplement. However, information regarding heavy DIM supplementation is scarce, and whether or not DIM use is safe on a long-term basis is not known. In this study, we compare the effects of two concentrations of DIM on the expression of AhR and ER $\alpha$ target genes, as well as test their impact on AhR-ER $\alpha$ crosstalk. We chose a lower concentration of DIM (10 $\mu \mathrm{M}$; thereafter the 'low concentration'), which can theoretically be reached in the human body by a 'heavy eater' of cruciferous vegetables, and a higher concentration (50 $\mu \mathrm{M}$; thereafter the 'high concentration'), which is known to possess strong anti-proliferative effects in cancer cells. Our results indicate an opposite dose-dependent effect of DIM in MCF7 and T47D cells in the absence of E2. At the high concentration, DIM inhibits cell proliferation and induces both $p 21$ and CYP1A1 gene expression. At the low concentration, in the absence of E2, DIM acts as an estrogen mimetic and induces ER $\alpha$ target gene expression and concomitant cellular proliferation. Moreover, we find that the estrogenic effects observed following DIM treatment are mediated by ER $\alpha$ and the PKA signaling pathway.

\section{Methods}

\section{Chemicals and reagents}

2,3,7,8-Tetrachlorodibenzo- $p$-dioxin (TCDD) was obtained from Cerilliant Cambridge isotope Laboratories (catalogue \#ED-901-C). 17ß-Estradiol (E2) and ICI 182,780 (ICI) were purchased from Sigma-Aldrich. 3,3'-diindolylmethane (DIM) was purchased from LKT Laboratories, Inc. (catalogue \#D3232), and H89 was purchased from Cayman chemical (catalogue \#10010556).

\section{Cell culture and treatments}

MCF7, T47D, and MDAMB-231 cell lines from American Type Culture Collection were maintained in DMEM (Wisent) containing 10\% fetal bovine serum (FBS) and antibiotics. For all the experiments, cells were grown in phenol red free DMEM medium (Wisent) containing 5\% dextran-coated charcoal-treated FBS and antibiotics for three days and then treated with different combinations of chemicals. For expression assays, we treated the cells for $24 \mathrm{~h}$ with $10 \mathrm{nM}$ TCDD, $10 \mu \mathrm{M}$ or $50 \mu \mathrm{M}$ DIM, 100 nM E2. For ChIP assays, we treated cells with the same concentrations as described for the expression assays, but for $90 \mathrm{~min}$ with TCDD and TCDD + E2, and for 60 min with DIM and DIM + E2. In experiments with ICI H89, and PD98059, we added these chemicals $24 \mathrm{~h}$ prior to other treatments.

\section{RNA isolation and reverse transcription PCR}

Cells were seeded in 6-well plates at a density of $0.35 \times$ $10^{6}$ cells per well. The day after, the cells were washed twice with PBS and put in estrogen-free media for 3 days. The cells were incubated with ligands for $24 \mathrm{~h}$. Total RNA was extracted from cells using Genelute (Sigma). cDNA was synthesized from 600 ng of total RNA using MMLV-RT (Promega).

\section{Quantitative real-time PCR}

The synthesized cDNA was diluted to $1: 8$ and $5 \mu \mathrm{l}$ of the dilution was used per reaction. Quantitative real-time 
PCR was performed using homemade $2 \mathrm{X}$ mix with SYBR Green, $2 \mathrm{mM} \mathrm{MgCl}$, and homemade Taq polymerase. We used qPCR primers for $36 B 4$ as the internal control during qPCR. Human CYP1A1, CYP1B1, GREB1, TFF1 and $p 21$ mRNAs were quantified with the following primers: RT 36B4 Fwd-CGACCTGGAAGTCCAACTAC; RT 36B4 Rev-ATCTGCTGCATCTGCTTG; RT CYP1A1 Fwd-TGA ACCCCAGGGTACAGAGA; RT CYP1A1 Rev-GGCCTCC ATATAGGGCAGAT; RT CYP1B1 Fwd-AACGTACCGG CCACTATCAC; RT CYP1B1 Rev-CCACGACCTGATCC AATTCT; RT GREB1 Fwd-CGTTGGAAATGGAGACA AGG; RT GREB1 Rev-CTCTGCCTGAAGGATGCTGT; RT TFF1 Fwd-GTGCAAATAAGGGCTGCTGT; RT TFF1 Rev-GCACATCCCTGCAGAAGTGT; RT $p 21$ Fwd-GGA GACTCTCAGGGTCGAAA; RT $p 21$ Rev-GGATTAGG GCTTCCTCTTGG.

\section{ChIP assays}

ChIP assays were performed essentially as described previously [33]. Briefly, cells were crosslinked with $1.1 \%$ formaldehyde for 10 minutes and then quenched with $125 \mathrm{mM}$ glycine. Samples were sonicated to generate chromatin fragments $<500 \mathrm{bp}$. Next, the chromatin was immunoprecipitated with specific antibodies against AhR (SantaCruz) and ER $\alpha$ (SantaCruz). qPCR was performed using a set of primers relevant to the promoter regions of the CYP1A1. The primers used in qPCR are ChIP CYP1A1-A FwdCAGCACTAAGGCGATCCTAGA; ChIP CYP1A1-A RevGATTGAAGGATCGGAATGGA. Results are shown as percent of input.

\section{Cell proliferation assay}

Cells were seeded in 48-well plates at a density of $1.5 \times$ $10^{4}$ cells per well in estrogen-free media for three days and then treated with either DMSO; $100 \mathrm{nM}$ E2; $10 \mu \mathrm{M}$ DIM; $50 \mu \mathrm{M}$ DIM; $50 \mu \mathrm{M}$ ICI; $10 \mu \mathrm{M}$ H89; $10 \mu \mathrm{M}$ DIM and $50 \mu \mathrm{M}$ ICI; or $10 \mu \mathrm{M}$ DIM and $10 \mu \mathrm{M}$ H89. Medium was replaced every two days. At each time point, cells were collected, fixed with $4 \%$ formaldehyde for $15 \mathrm{~min}$, and kept in $0.4 \%$ formaldehyde/PBS $1 \mathrm{X}$ at $4^{\circ} \mathrm{C}$ until the last end point was reached. The cells were then washed once with sterile distilled water and colored with $0.5 \mathrm{~mL}$ of $0.1 \%$ crystal violet in $10 \%$ ethanol for $20 \mathrm{~min}$. The cells were washed three times with sterile distilled water and allowed to air dry. The dye was extracted with $0.5 \mathrm{~mL}$ of $10 \%$ acetic acid for $20 \mathrm{~min}$. Absorbance was measured at $590 \mathrm{~nm}$ in 96-well plates. The values are presented as fold over day 0 . Each treated time-point is the average of nine wells from three independent experiments and the error bars represent standard deviation.

\section{FACS}

Cells were rinsed with PBS, treated with trypsin and collected. The cells were then fixed in cold $70 \%$ ethanol, resuspended in $50 \mathrm{mM}$ sodium citrate $\mathrm{HCl} \mathrm{pH} \mathrm{7.0,} \mathrm{and}$ treated successively with RNase A and proteinase $\mathrm{K}$. Finally, the cells were resuspended in Sytox Green (Life Technologies) dye at a final concentration of $1 \mu \mathrm{M}$ in the same buffer. Samples were analysed by flow cytometry on a Becton Dickinson FACScalibur cytometer. For each sample, ten thousand cells were plotted on a histogram with FL-1 on the X-axis and gates were set to distinguish cells in G1, S, G2/M and sub-G1-phases of the cell cycle. Data in the figure are expressed as a percentage of all gated cells in the sample and represent the average and standard error of triplicate experiments.

\section{Results}

Opposing effects of two AhR agonists on ERa-mediated repression of CYP1A1 expression

CYP1A1 expression was first measured in MCF7 breast cancer cells that were grown in estrogen-free medium for three days and then treated with either $10 \mathrm{nM}$ TCDD or $50 \mu \mathrm{M}$ DIM, alone, or in combination with $100 \mathrm{nM}$ E2 for $24 \mathrm{~h}$. Co-treatment of cells with E2 and TCDD typically decreased CYP1A1 activation by $60 \%$ when compared to TCDD alone (Figure 1A; [33]). Following DIM treatment, CYP1A1 activity reached levels similar to those found in TCDD + E2 treated cells. Addition of E2 produced no effect on DIM-induced CYP1A1 expression (Figure 1A). Similar results were also obtained in T47D cells, but we observed a more modest repression effect by E2, as well as weaker activation of CYP1A1 (see Additional file 1: Figure S1A). We also monitored CYP1A1 protein levels upon TCDD treatment of cells, and, as expected, the observed effects on transcription correlated with CYP1A1 protein expression levels (Additional file 1: Figure S1B). To further investigate this phenomenon, we sought to verify the recruitment of $\mathrm{AhR}$ and ER $\alpha$ at the CYP1A1 proximal promoter by ChIP experiments. As expected from the expression results, co-treatment of cells with TCDD and E2 impairs AhR binding at the CYP1A1 promoter as compared to TCDD alone (Figure 1C). For the DIM treated cells, we observed no significant variation of AhR binding when E2 was added (Figure 1C). ER $\alpha$ recruitment to the CYP1A1 promoter is known to occur only when $A h R$ and $E R \alpha$ signaling pathways are simultaneously activated [34]. Our results are consistent with this, since ER $\alpha$ is present at the CYP1A1 promoter only after treatment with TCDD + E2, but not after addition of TCDD alone (Figure 1D). Treatment of cells with DIM alone, or in combination with E2, resulted in the recruitment of both AhR (Figure 1C) and ER $\alpha$ (Figure 1D). This is consistent with the finding that DIM activates both AhR and ER $\alpha$ signaling pathways [30,35]. Altogether, these results show that $C Y P 1 A 1$ expression and $A h R$ and $E R \alpha$ binding at the CYP1A1 promoter are differentially regulated by TCDD and DIM. 


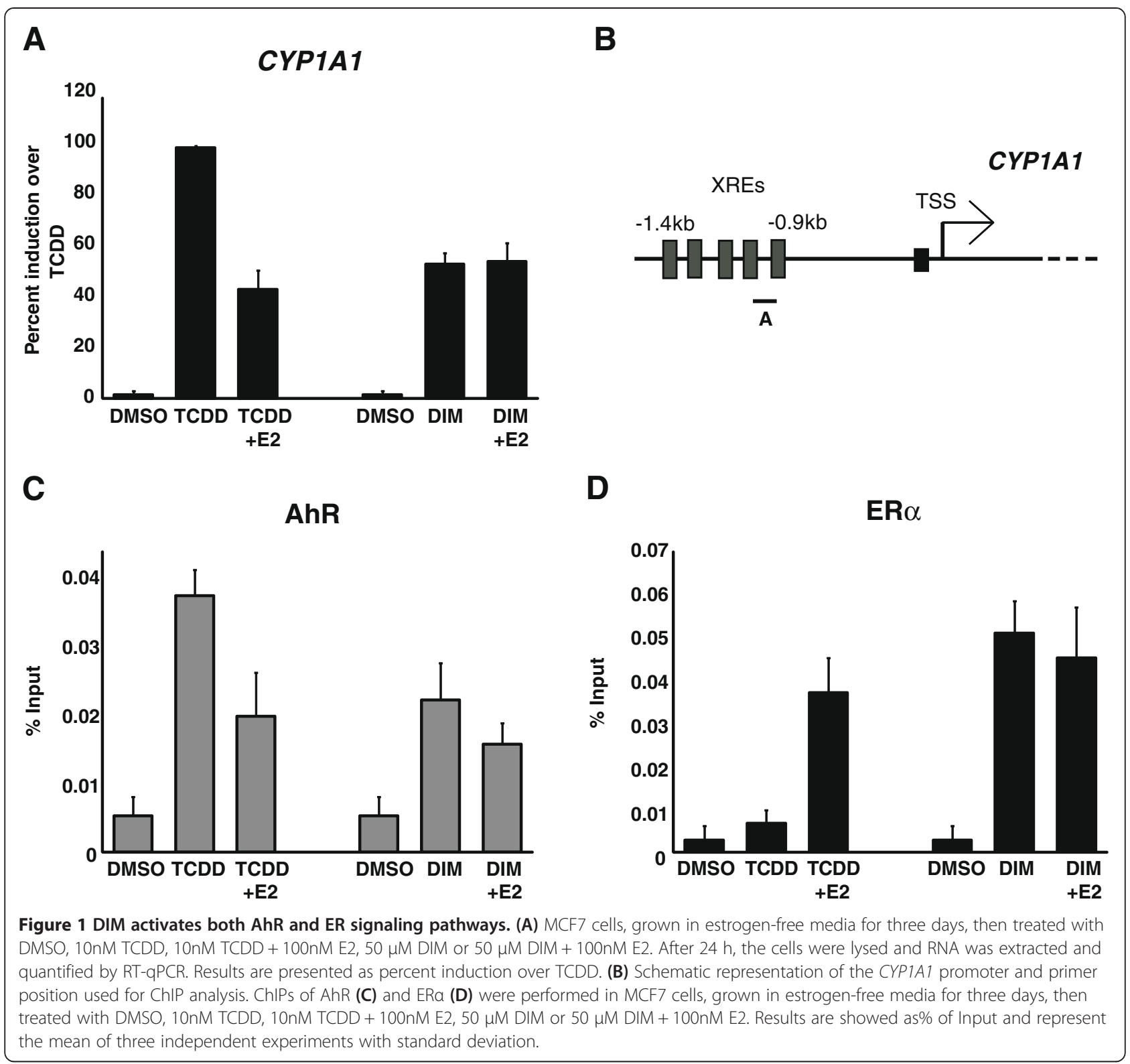

Inhibition of ERa increases CYP1A1 induction in response to DIM

DIM is documented to be a weak AhR ligand when compared to TCDD and has been described as an antagonist of AhR-mediated gene transcription [30]. Considering the repressive effect of ER $\alpha$ on AhR signaling, the activation of ER $\alpha$ by DIM treatment might partly explain the weaker induction of CYP1A1. This scenario could also explain why co-treatment of cells with both TCDD and DIM leads to weaker induction of AhR target genes in $\mathrm{ER} \alpha$ positive cells $[30,36]$. We next wanted to verify if depletion of ER $\alpha$ would allow an increase in CYP1A1 expression after DIM treatment. First, MCF7 cells were grown in E2-depleted media for three days and then treated with $50 \mu \mathrm{M}$ ICI 182780 (a specific ER $\alpha$ inhibitor also known as Fulvestran) for $24 \mathrm{~h}$ prior to the addition of $50 \mu \mathrm{M}$ DIM for another $24 \mathrm{~h}$. We observed a twofold increase in CYP1A1 induction in cells treated with DIM and ICI compared to DIM alone (Figure 2A). A similar experiment was performed using T47D breast cancer cells and the results obtained (Additional file 2: Figure S2) were very comparable to those obtained in Figure 2A. ChIP experiments performed at the CYP1A1 promoter using AhR and ER $\alpha$ antibodies show that AhR binding increases when cells are co-treated with DIM and ICI 182780 (Figure 2B), and that ICI 182780 prevents $\mathrm{ER} \alpha$ from being recruited to $C Y P 1 A 1$ (Figure 2C). The latter result is consistent with a previous study that showed that ICI leads to ER $\alpha$ degradation [37]. Overall, our data indicate a dual role of DIM in the regulation of 


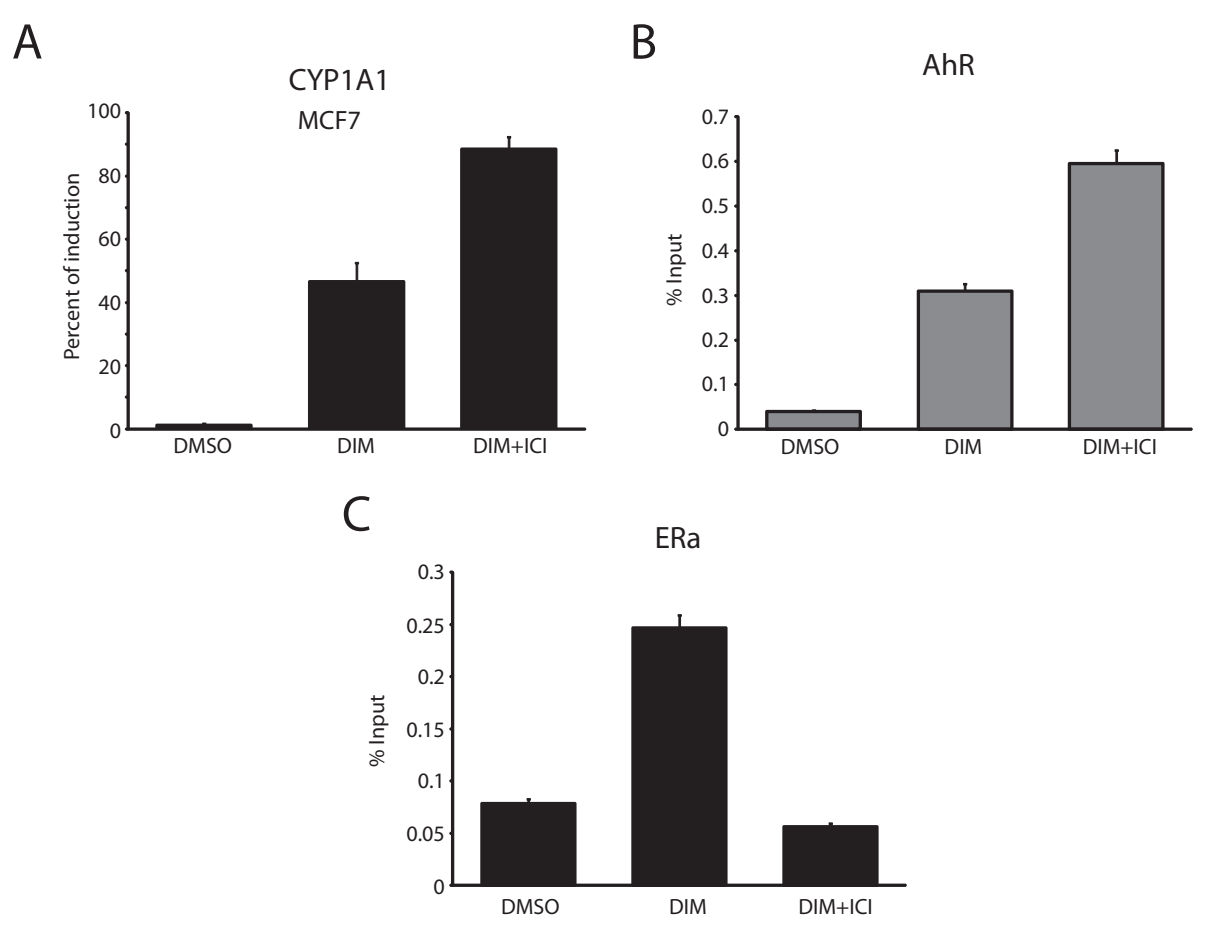

Figure 2 ERa degradation increases CYP1A1 induction in response to DIM. (A) Expression analyses were performed in MCF7 cells grown in estrogen-free media for three days and treated with $50 \mu \mathrm{M} \mathrm{ICl} 182780$ for $24 \mathrm{~h}$ prior to the addition of $50 \mu \mathrm{M}$ DIM for $24 \mathrm{~h}$. ChIPs of AhR (B) and ERa (C) were performed in MCF7 cells, grown in estrogen-free media for three days and then treated or not with $50 \mu \mathrm{M} \mathrm{ICl} 182780$ for $24 \mathrm{~h}$ prior to the addition of $50 \mu \mathrm{M}$ DIM for $1 \mathrm{~h}$. Results are shown as\% of Input and represent the mean of three independent experiments with standard deviation.

CYP1A1 expression. On one hand, DIM binds AhR and promotes CYP1A1 induction, while on the other, DIM triggers $\mathrm{ER} \alpha$ activation and represses CYP1A1 expression.

\section{Different concentrations of DIM preferentially activate either the AhR or ERa signaling pathways}

In the experiments described above, we used $50 \mu \mathrm{M}$ DIM, which is considered to be very high (the high concentration). For instance, Leong and co-workers proposed that a heavy eater of Brassica vegetables could reach, under optimal conditions, a DIM blood concentration of approximately $10 \mu \mathrm{M}$ [35]. Thus, we decided to compare a potential physiological concentration of DIM (low concentration $=10 \mu \mathrm{M})$ with the high concentration $(50 \mu \mathrm{M})$. We treated MCF7 cells grown in estrogen-free media for three days with the low and the high concentrations of DIM and then measured the mRNA levels of two AhR target genes (CYP1A1 and CYP1B1), as well as two ER $\alpha$ target genes (GREB1 and TFF1). We observed an increase in gene expression that is directly proportional to DIM concentrations for the AhR target genes (Figure 3A and B). Strikingly, the low concentration of DIM strongly induces ER $\alpha$ target gene expression, whereas the high concentration has almost no effect on the expression of these genes (Figure 3C and D). GREB1 protein levels were also monitored by immunoblotting using cells treated with $10 \mu \mathrm{M}$ DIM (Additional file 3: Figure S3A). The results parallel the mRNA expression levels and show that GREB1 is induced by $10 \mu \mathrm{M}$ DIM. Taken together, our results suggest that physiological concentrations of DIM stimulate transcriptional activity of ER $\alpha$-dependent genes in the absence of E2 in MCF7 cells. We also repeated these same experiments in T47D cells and obtained nearly identical results (Additional file 3: Figure S3B), a result that shows that these effects are not cell-type specific.

\section{The PKA signaling pathway contributes to DIM-mediated} ligand-independent activation of ERa

A previous study using reporter assays has shown that the activation of ER $\alpha$ by DIM is independent of its binding to ER $\alpha$ and involves the PKA signaling pathway and, to a lesser extent, the MAPK pathway [32]. To test the role of the PKA signaling pathway in ER $\alpha$ activation by DIM, we used a specific inhibitor of the PKA pathway, H89. We measured mRNA levels of $C Y P 1 A 1$, which is negatively regulated by $E R \alpha$, and GREB1, which is positively regulated by ER $\alpha$. MCF7 cells grown in E2depleted media were treated with either $100 \mathrm{nM} \mathrm{E2}$, $10 \mu \mathrm{M}$ DIM, $10 \mu \mathrm{M}$ DIM + $50 \mu \mathrm{M}$ ICI, or $10 \mu \mathrm{M}$ DIM + $10 \mu \mathrm{M} \mathrm{H} 89$ for $24 \mathrm{~h}$. Figure 4A shows that both the ICI 
A

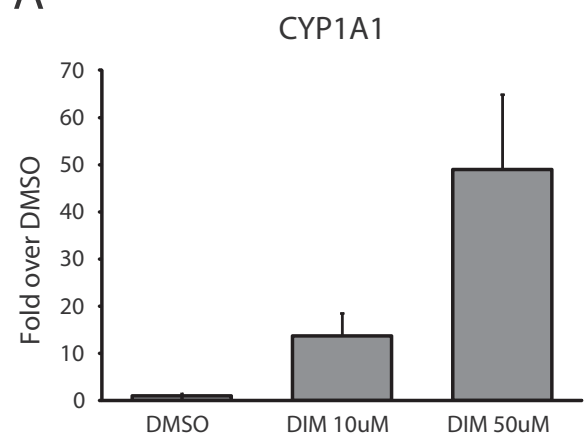

C

GREB1

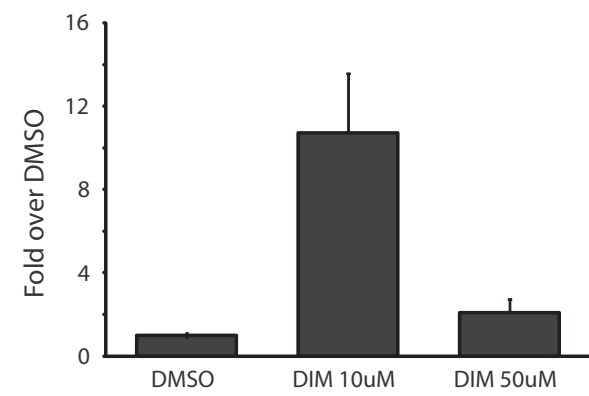

B

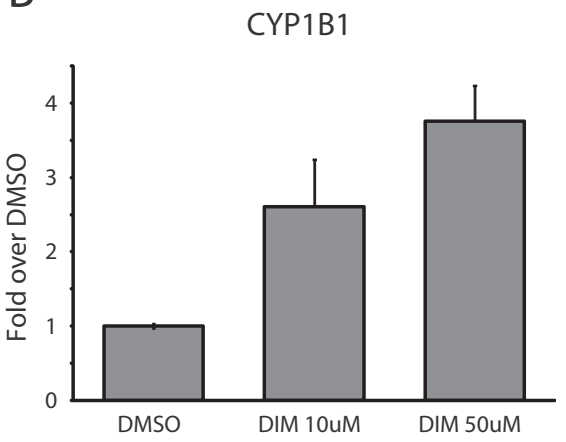

D

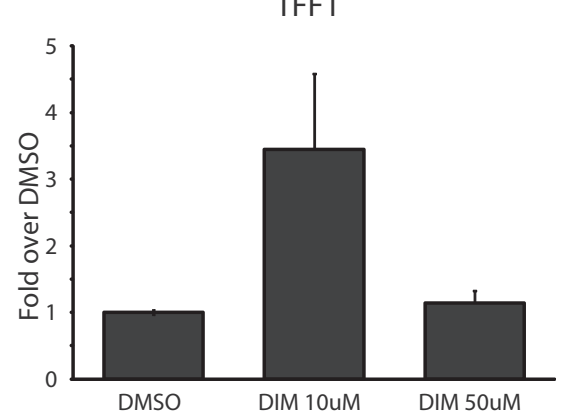

Figure 3 Effects of different concentrations of DIM on AhR and ERa target gene expression. mRNA levels of AhR target genes CYP1A1 (A) and CYP1B1 (B) and ERa target genes GREB1 (C) and TFF1 (D) were quantified in MCF7 cells grown in estrogen-free media for three days, then treated with DMSO, $10 \mu \mathrm{M}$ DIM or $50 \mu \mathrm{M}$ DIM for $24 \mathrm{~h}$. Results are shown as fold over DMSO and represent the mean of three independent experiments with standard deviation.

and $\mathrm{H} 89$ treatments of cells abrogate the repression mediated by ER $\alpha$ on CYP1A1 gene expression. Conversely, we observed that ICI and H89 abolish the induction of GREB1 by DIM (Figure 4B). As with the previous figures, we performed the same experiments in T47D cells and obtained comparable results (Additional file 4: Figure S4). In conclusion, DIM mediates ER $\alpha$ activation, at least in large part, via the action of the PKA signaling pathway.

Low concentrations of DIM induce MCF7 proliferation in the absence of E2

It is known that high concentrations of DIM $(>50 \mu \mathrm{M})$ have antiproliferative and antitumor properties in almost
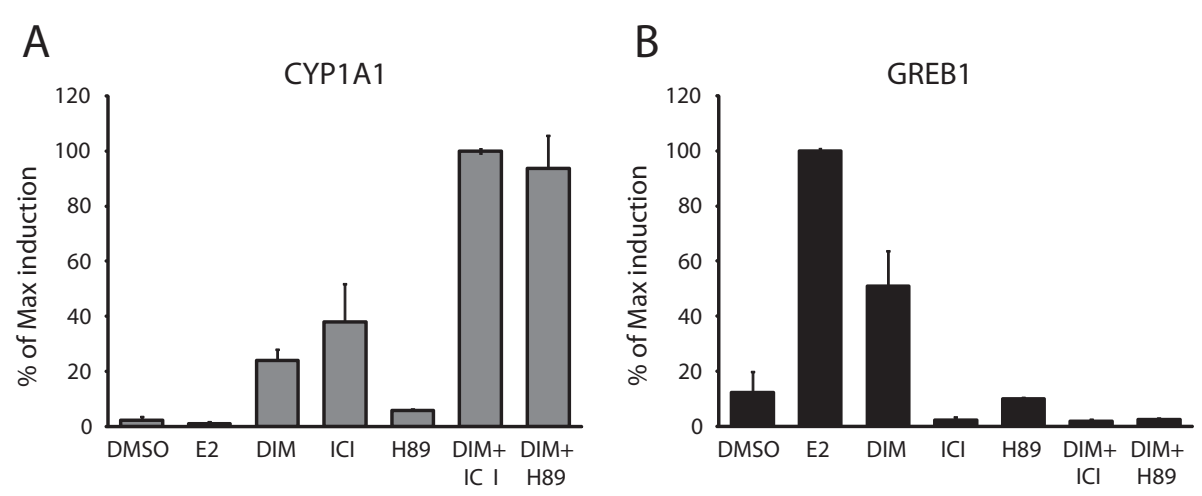

Figure 4 DIM ligand-independent activation of ER $a$ is mediated by the PKA signaling pathway. CYP1A1 mRNA level (A) and GREB1 mRNA level (B) in MCF7 cells grown in estrogen-free media for three days and then treated or not with $50 \mu \mathrm{M} \mathrm{ICl}$ or $10 \mu \mathrm{M} \mathrm{H89}$ for $24 \mathrm{~h}$ prior to the addition of DMSO, 100nM E2, $10 \mu \mathrm{M}$ DIM, $10 \mu \mathrm{M}$ DIM + 50 $\mu \mathrm{M}$ ICI or $10 \mu \mathrm{M}$ DIM + $10 \mu \mathrm{M}$ H89 for $24 \mathrm{~h}$. Results are shown as percent of maximum induction and represent the mean of three independent experiments with standard deviation. 
all cancer cell lines that have been tested [23,24,26]. Moreover, some of these properties have been proposed to work via induction of the $p 21$ gene, a key regulator of the cell cycle associated with G1 arrest and senescence [38]. Conversely, since a low dose of DIM activates ER $\alpha$, it might also promote cellular proliferation. We thus decided to compare the effect of both DIM concentrations on cellular proliferation. We first verified the effect of high and low-dose DIM treatments on the expression of $p 21$ by RT-qPCR. We observe that only the high concentration of DIM induces $p 21$ expression in MCF7 cells (Figure 5A). We then compared MCF7 cell proliferation using crystal violet staining in E2-depleted media following three days of treatment with either E2, $10 \mu \mathrm{M}$ DIM or $50 \mu \mathrm{M}$ DIM (Figure 5B). Strikingly, the two concentrations of DIM have opposite effects on cellular proliferation. On the one hand, a low concentration of DIM stimulates cell growth almost as much as E2 treatment. On the other hand, a high concentration of DIM inhibits cell growth (Figure 5B). To verify that the observed effects of the low concentration of DIM on cellular proliferation were mediated by ER $\alpha$ and the PKA pathway, we treated MCF7 cells with either ICI or H89, in addition to DIM (Figures $5 \mathrm{C}, \mathrm{D}$ ). Both the degradation of ER $\alpha$ and the inhibition of the PKA signaling pathway abrogated the proliferative effect of DIM in the absence of E2. Similar experiments were conducted in T47D cells with comparable results (Additional file 5).

In order to further confirm the effects of DIM on the cell cycle, we performed cell cycle assays using flow cytometry (FACS) in T47D cells (Additional file 5: Figure S5B). The results show that at low concentrations of DIM $(10 \mu \mathrm{M})$ the percentage of cells in S-phase is significantly increased compared to DMSO-treated cells, indicating a higher proliferation rate similar to cells treated with E2 (Additional file 6). Cells treated with $50 \mu \mathrm{M}$ DIM tended to have a lower percentage of S-phase cells than untreated cells, although the difference was not statistically significant ( $p$-value $=0.06)$. Finally, we performed a FACS experiment under the same conditions but with MDAMB-232 cells, which do not express the ER $\alpha$. As expected, DIM has no significant effect (Additional file 6) on cell growth in this cell line, confirming that the proliferative effect of DIM is a result of activating the ER $\alpha$ pathway. In conclusion, we observed that treatment with the low concentration of DIM induced breast cancer cell proliferation in the absence of E2, an effect mediated by ER $\alpha$ and the PKA signaling pathway.

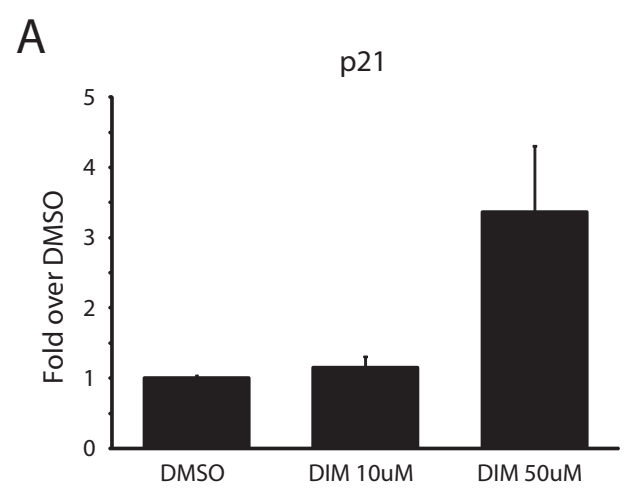

\section{B}
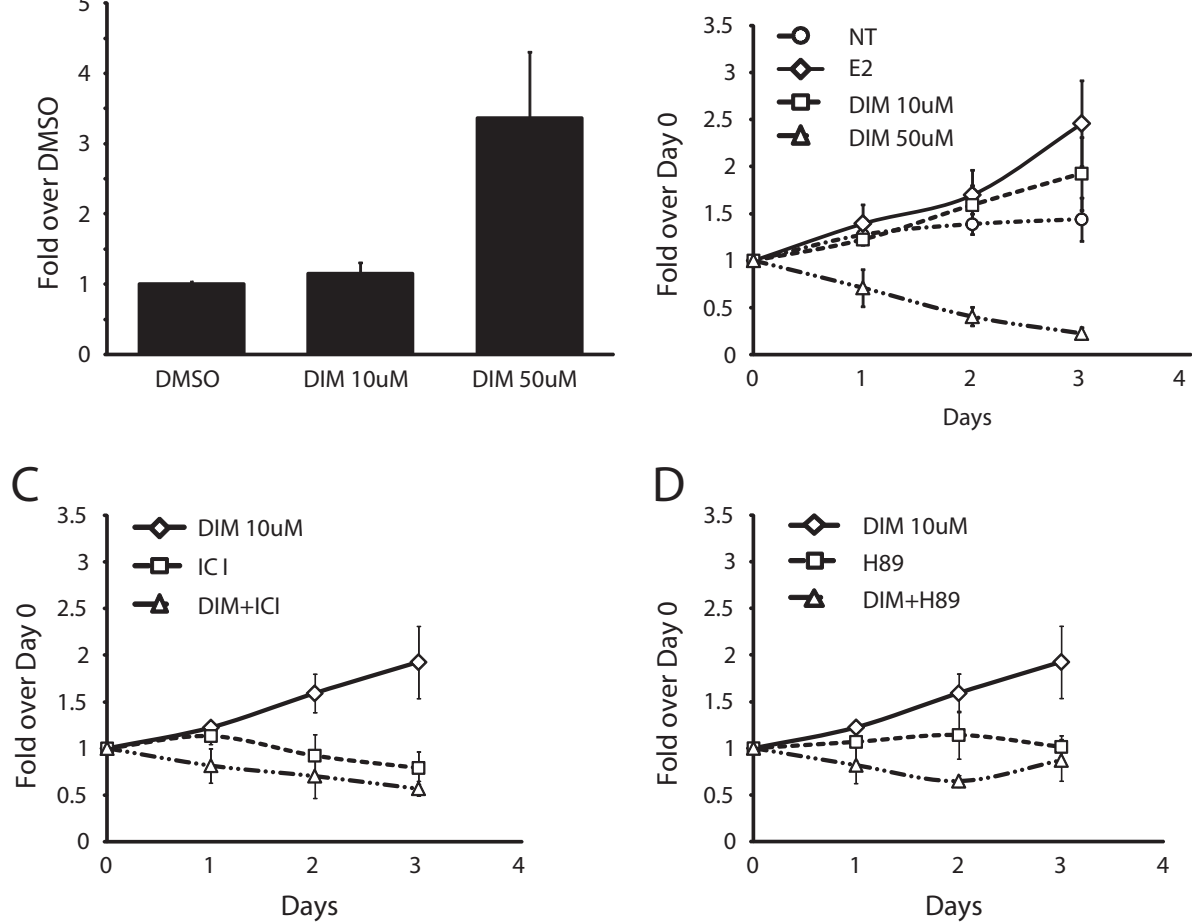

Figure 5 Low concentration of DIM induces MCF7 proliferation in absence of E2. (A) p21 expression was quantified in MCF7 cells grown in estrogen-free media for three days and then treated with DMSO, $10 \mu \mathrm{M}$ DIM or $50 \mu \mathrm{M}$ DIM for $24 \mathrm{~h}$. (B) Proliferation assay of MCF7 cells, first grown in estrogen-free media and then treated (DMSO, ER, DIM $10 \mu \mathrm{M}$ or $50 \mu \mathrm{M}$ ) over three days. (C) Proliferation assay of MCF7 cells treated with $10 \mu \mathrm{M}$ DIM with or without ICI 182 780. (D) Proliferation assay of MCF7 cells treated with $10 \mu \mathrm{M}$ DIM with or without H89. 


\section{Discussion}

Bidirectional inhibitory crosstalk between AhR and ER $\alpha$ is very complex and occurs at many regulatory levels [39,40]. AhR ligands have been shown to carry potentially important chemopreventive properties, thus understanding the mechanisms behind these properties is fundamental for developing cancer therapies. DIM has been intensely studied as a possible therapeutic agent in cancer treatment, especially for breast cancer. Studies report that DIM treatment promotes cellular growth arrest of cancer cells, as well as a decrease in mammary tumor formation in DMBA-treated rats $[16,24,30]$. Although the use of DIM as a therapeutic agent in the treatment of breast cancer is not yet approved, there are active clinical trials that are testing DIM for the treatment of many types of cancers (http://clinicaltrials.gov/ ct2/results?term=diindolylmethane). However, DIM can easily be purchased as a dietary supplement and be selfadministered. As previously mentioned, DIM is a SAhRM that binds AhR, which is involved in the regulation of the expression of phase I and II drug metabolizing enzymes. Discrepancies are found in the literature as to whether DIM is an agonist or an antagonist of AhR [27-31], thus, clarification of this issue is important, especially regarding the potentially toxic effect mediated by AhR agonists in the liver following AhR activation.

In this study, we tested how the use of different concentrations of DIM can lead to opposite biological outcomes. As previously reported, we confirmed that activation of ER $\alpha$ by E2 represses the induction of CYP1A1 by approximately $60 \%$ after TCDD treatment. The simultaneous activation of AhR and ER $\alpha$ when cells are treated with DIM does not allow full induction of CYP1A1. Furthermore, addition of E2 to DIM-treated cells has no repressive effect on CYP1A1 expression, which can be explained by the fact that $\mathrm{ER} \alpha$ is already fully recruited to the $C Y P 1 A 1$ promoter after DIM treatment alone. We propose that activation of ER $\alpha$ by DIM can explain, at least in part, some discrepancies found in the literature on the role of DIM as an agonist/antagonist of $\mathrm{AhR}$ in ER $\alpha$ positive cell lines [27-31].

DIM concentrations found in the human body are dependent on the diet. Our first experiments were carried out using a concentration of $50 \mu \mathrm{M}$, which is probably much higher than what can realistically be reached in the body [35]. We then compared $50 \mu \mathrm{M}$ DIM with a more physiological concentration of DIM $(10 \mu \mathrm{M})$ and observed that the high concentration of the compound induces the expression of AhR target genes (CYP1A1 and CYP1B1), while the low concentration shows significant effects on the expression of ER $\alpha$ target genes (GREB1 and TFF1) in the absence of E2. These observations indicate that at physiological concentrations, DIM principally mediates estrogenic effects. It can also explain why oral administration of DIM in rodents has no hepatic toxicity due to the weak induction of the
CYP1A1 gene at this low concentration. ER $\alpha$ activation can be mediated by direct binding of its main ligand (E2), but it can also be induced by the activation of the PKA signaling pathway. The phosphorylation of ER $\alpha$ increases its capacity to interact with the transcription machinery and triggers the expression of ER $\alpha$ target genes [41-44]. Accordingly, we were able to demonstrate that the effect of DIM treatment on CYP1A1 and GREB1 expression is mediated by $E R \alpha$, which, in this case, is activated mostly by the PKA signaling pathway.

\section{Conclusions}

The estrogen receptor is highly expressed in almost 70\% of breast cancer cases and its activation promotes cellular proliferation and tumor development [45]. Our results demonstrate that DIM, at concentrations likely attainable by a diet rich in cruciferous vegetables, induces proliferation of MCF7 and T47D breast cancer cells in the absence of E2. DIM requires that ER $\alpha$ be activated by the PKA signaling pathway to promote cellular growth in the absence of E2. Consequently, the abundance of ER $\alpha$, as well as circulating estrogen levels, will influence the local effects of DIM on cell growth. Altogether, our findings suggest that the use of DIM as a dietary supplement or as a therapeutic agent should be undertaken very cautiously as unexpected adverse effects could be encountered.

\section{Additional files}

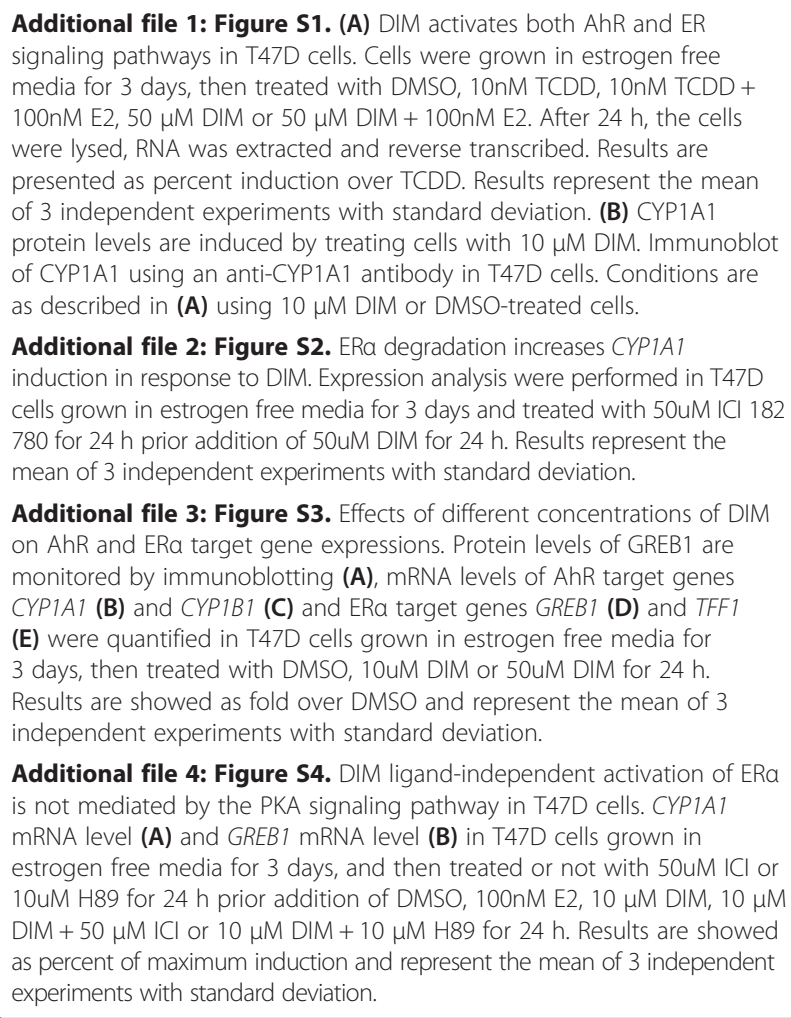

Additional file 2: Figure S2. ERa degradation increases CYP1A1 induction in response to DIM. Expression analysis were performed in T47D cells grown in estrogen free media for 3 days and treated with 50uM ICI 182 780 for $24 \mathrm{~h}$ prior addition of 50uM DIM for $24 \mathrm{~h}$. Results represent the mean of 3 independent experiments with standard deviation.

Additional file 3: Figure S3. Effects of different concentrations of DIM on AhR and ERa target gene expressions. Protein levels of GREB1 are monitored by immunoblotting (A), mRNA levels of AhR target genes CYP1A1 (B) and CYP1B1 (C) and ERa target genes GREB1 (D) and TFF1 (E) were quantified in T47D cells grown in estrogen free media for 3 days, then treated with DMSO, 10uM DIM or 50uM DIM for $24 \mathrm{~h}$. Results are showed as fold over DMSO and represent the mean of 3 independent experiments with standard deviation.

Additional file 4: Figure S4. DIM ligand-independent activation of ERa is not mediated by the PKA signaling pathway in T47D cells. CYP1A1 mRNA level (A) and GREB1 mRNA level (B) in T47D cells grown in estrogen free media for 3 days, and then treated or not with $50 \mathrm{uM} \mathrm{ICl}$ or 10uM H89 for $24 \mathrm{~h}$ prior addition of DMSO, 100nM E2, $10 \mu \mathrm{M} \mathrm{DIM}, 10 \mu \mathrm{M}$ $\mathrm{DIM}+50 \mu \mathrm{M} \mathrm{ICI}$ or $10 \mu \mathrm{M} \mathrm{DIM}+10 \mu \mathrm{M}$ H89 for $24 \mathrm{~h}$. Results are showed as percent of maximum induction and represent the mean of 3 independent experiments with standard deviation. 
Additional file 5: Figure S5. Low concentration of DIM induces T47D proliferation in the absence of E2. (A) p21 expression was quantified in T47D cells grown in estrogen free media for 3 days and then treated with DMSO, $10 \mu \mathrm{M}$ DIM and $50 \mu \mathrm{M}$ DIM for $24 \mathrm{~h}$. Proliferation of T47D cells, grown in estrogen free media, was analyzed following various treatments during 3 days. (B) Comparison of T47D cell proliferation after DMSO, 100nM E2, $10 \mu \mathrm{M}$ DIM and 50 MM DIM treatments. (C) Effect of IC 182780 on T47D cell proliferation induced by $10 \mu \mathrm{M}$ DIM treatment.

Additional file 6: Figure S6. FACS analysis of cells treated with either 10 or 50 MM DIM. (A) T47D or (B) MDAMB-231 cells. Bar plot shows the percentage of S-phase cells in each sample.

\section{Competing interests}

The authors declare that they have no competing interests.

\section{Authors' contributions}

$M M, L L, I B, C C$, and $B G$ performed the experiments. $L G$ and $M M$ conceived the experiments and wrote the manuscript. All authors read and approved the final manuscript.

\section{Acknowledgements}

We are grateful to Jean-François Millau for discussions and critical reading of the manuscript. This work was supported by a grant from the Canadian Institutes of Health Research (grant MOP-93620 awarded to LG) and a Canada Research Chair on Mechanisms of Gene Transcription (awarded to LG).

Received: 9 January 2014 Accepted: 8 July 2014

Published: 21 July 2014

\section{References}

1. Parl FF, Dawling S, Roodi N, Crooke PS: Estrogen metabolism and breast cancer: a risk model. Ann N Y Acad Sci 2009, 1155:68-75

2. Martucci CP, Fishman J: P450 enzymes of estrogen metabolism. Pharmacol Ther 1993, 57:237-257.

3. Tsuchiya Y, Nakajima M, Yokoi T: Cytochrome P450-mediated metabolism of estrogens and its regulation in human. Cancer Lett 2005, 227:115-124.

4. Martucci C, Fishman J: Direction of estradiol metabolism as a control of its hormonal action-uterotrophic activity of estradiol metabolites. Endocrinology 1977, 101:1709-1715.

5. Cavalieri EL, Stack DE, Devanesan PD, Todorovic R, Dwivedy I, Higginbotham S, Johansson SL, Patil KD, Gross ML, Gooden JK, Ramanathan R, Cerny RL, Rogan EG: Molecular origin of cancer: catechol estrogen-3,4-quinones as endogenous tumor initiators. Proc Natl Acad Sci U S A 1997, 94:10937-10942.

6. Zhao Z, Kosinska W, Khmelnitsky M, Cavalieri EL, Rogan EG, Chakravarti D, Sacks PG, Guttenplan JB: Mutagenic activity of 4-hydroxyestradiol, but not 2-hydroxyestradiol, in BB rat2 embryonic cells, and the mutational spectrum of 4-hydroxyestradiol. Chem Res Toxicol 2006, 19:475-479.

7. Li KM, Todorovic R, Devanesan P, Higginbotham S, Kofeler H, Ramanathan R, Gross ML, Rogan EG, Cavalieri EL: Metabolism and DNA binding studies of 4-hydroxyestradiol and estradiol-3,4-quinone in vitro and in female ACl rat mammary gland in vivo. Carcinogenesis 2004, 25:289-297.

8. Belous AR, Hachey DL, Dawling S, Roodi N, Parl FF: Cytochrome P450 1B1mediated estrogen metabolism results in estrogen-deoxyribonucleoside adduct formation. Cancer Res 2007, 67:812-817.

9. Fernandez SV, Russo IH, Russo J: Estradiol and its metabolites 4hydroxyestradiol and 2-hydroxyestradiol induce mutations in human breast epithelial cells. Int J Cancer 2006, 118:1862-1868.

10. Murray GI, Taylor MC, McFadyen MC, McKay JA, Greenlee WF, Burke MD, Melvin WT: Tumor-specific expression of cytochrome P450 CYP1B1. Cancer Res 1997, 57:3026-3031.

11. Yang $X$, Solomon $S$, Fraser $L R$, Trombino AF, Liu D, Sonenshein GE, Hestermann EV, Sherr DH: Constitutive regulation of CYP1B1 by the aryl hydrocarbon receptor (AhR) in pre-malignant and malignant mammary tissue. J Cell Biochem 2008, 104:402-417.

12. Coumoul X, Diry M, Robillot $C$, Barouki R: Differential regulation of cytochrome P450 $1 \mathrm{~A} 1$ and $1 \mathrm{~B} 1$ by a combination of dioxin and pesticides in the breast tumor cell line MCF-7. Cancer Res 2001, 61:3942-3948

13. Kociba RJ, Keyes DG, Beyer JE, Carreon RM, Wade CE, Dittenber DA, Kalnins RP, Frauson LE, Park CN, Barnard SD, Hummel RA, Humiston CG:
Results of a two-year chronic toxicity and oncogenicity study of 2,3,7,8-tetrachlorodibenzo-p-dioxin in rats. Toxicol Appl Pharmacol $1978,46: 279-303$

14. Gierthy JF, Lincoln DW 2nd: Inhibition of postconfluent focus production in cultures of MCF-7 human breast cancer cells by 2,3,7,8-tetrachlorodibenzop-dioxin. Breast Cancer Res Treat 1988, 12:227-233.

15. Gierthy JF, Lincoln DW, Gillespie MB, Seeger Jl, Martinez HL, Dickerman HW Kumar SA: Suppression of estrogen-regulated extracellular tissue plasminogen activator activity of MCF-7 cells by 2,3,7,8-tetrachlorodibenzo-p-dioxin. Cancer Res 1987, 47:6198-6203.

16. Chen I, McDougal A, Wang F, Safe S: Aryl hydrocarbon receptor-mediated antiestrogenic and antitumorigenic activity of diindolylmethane. Carcinogenesis 1998, 19:1631-1639.

17. Bjeldanes LF, Kim JY, Grose KR, Bartholomew JC, Bradfield CA: Aromatic hydrocarbon responsiveness-receptor agonists generated from indole-3carbinol in vitro and in vivo: comparisons with 2,3,7,8-tetrachlorodibenzo-p-dioxin. Proc Natl Acad Sci U S A 1991, 88:9543-9547.

18. Abbott DW, Ivanova VS, Wang X, Bonner WM, Ausio J: Characterization of the stability and folding of H2A.Z chromatin particles: implications for transcriptional activation. J Biol Chem 2001, 276:41945-41949.

19. Chang X, Tou JC, Hong C, Kim HA, Riby JE, Firestone GL, Bjeldanes LF: 3,3'Diindolylmethane inhibits angiogenesis and the growth of transplantable human breast carcinoma in athymic mice. Carcinogenesis 2005, 26:771-778.

20. Chen ZH, Hurh YJ, Na HK, Kim JH, Chun YJ, Kim DH, Kang KS, Cho MH, Surh YJ: Resveratrol inhibits TCDD-induced expression of CYP1A1 and CYP1B1 and catechol estrogen-mediated oxidative DNA damage in cultured human mammary epithelial cells. Carcinogenesis 2004, 25:2005-2013.

21. Chang X, Firestone GL, Bjeldanes LF: Inhibition of growth factor-induced Ras signaling in vascular endothelial cells and angiogenesis by 3,3'-diindolylmethane. Carcinogenesis 2006, 27:541-550.

22. Vivar OI, Lin CL, Firestone GL, Bjeldanes LF: 3,3'-Diindolylmethane induces a $\mathrm{G}(1)$ arrest in human prostate cancer cells irrespective of androgen receptor and p53 status. Biochem Pharmacol 2009, 78:469-476.

23. Choi HJ, Lim do Y, Park JH: Induction of G1 and G2/M cell cycle arrests by the dietary compound 3,3'-diindolylmethane in HT-29 human colon cancer cells. BMC Gastroenterol 2009, 9:39.

24. Hong C, Kim HA, Firestone GL, Bjeldanes LF: 3,3'-Diindolylmethane (DIM) induces a $\mathrm{G}(1)$ cell cycle arrest in human breast cancer cells that is accompanied by Sp1-mediated activation of p21(WAF1/CIP1) expression. Carcinogenesis 2002, 23:1297-1305.

25. Cao L, Kim S, Xiao C, Wang RH, Coumoul X, Wang X, Li WM, Xu XL, De Soto JA, Takai H, Mai S, Elledge SJ, Motoyama N, Deng CX: ATM-Chk2-p53 activation prevents tumorigenesis at an expense of organ homeostasis upon Brca1 deficiency. EMBO J 2006, 25:2167-2177.

26. Ge X, Yannai S, Rennert G, Gruener N, Fares FA: 3,3'-Diindolylmethane induces apoptosis in human cancer cells. Biochem Biophys Res Commun 1996, 228:153-158

27. Stresser DM, Bjeldanes LF, Bailey GS, Williams DE: The anticarcinogen 3,3'-diindolylmethane is an inhibitor of cytochrome P-450. J Biochem Toxicol 1995, 10:191-201.

28. Gross-Steinmeyer K, Stapleton PL, Liu F, Tracy JH, Bammler TK, Quigley SD, Farin FM, Buhler DR, Safe SH, Strom SC, Eaton DL: Phytochemical-induced changes in gene expression of carcinogen-metabolizing enzymes in cultured human primary hepatocytes. Xenobiotica 2004, 34:619-632.

29. Gross-Steinmeyer K, Stapleton PL, Tracy JH, Bammler TK, Strom SC, Buhler DR, Eaton DL: Modulation of aflatoxin B1-mediated genotoxicity in primary cultures of human hepatocytes by diindolylmethane, curcumin, and xanthohumols. Toxicol Sci 2009, 112:303-310.

30. Chen I, Safe S, Bjeldanes L: Indole-3-carbinol and diindolylmethane as aryl hydrocarbon (Ah) receptor agonists and antagonists in T47D human breast cancer cells. Biochem Pharmacol 1996, 51:1069-1076.

31. Hestermann EV, Brown M: Agonist and chemopreventative ligands induce differential transcriptional cofactor recruitment by aryl hydrocarbon receptor. Mol Cell Biol 2003, 23:7920-7925

32. Leong H, Riby JE, Firestone GL, Bjeldanes LF: Potent ligand-independent estrogen receptor activation by 3,3'-diindolylmethane is mediated by cross talk between the protein kinase $A$ and mitogen-activated protein kinase signaling pathways. Mol Endocrinol 2004, 18:291-302.

33. Marques M, Laflamme L, Gaudreau L: Estrogen receptor alpha can selectively repress dioxin receptor-mediated gene expression by targeting DNA methylation. Nucleic Acids Res 2013, 41:8094-80106. 
34. Beischlag TV, Perdew GH: ER alpha-AHR-ARNT protein-protein interactions mediate estradiol-dependent transrepression of dioxin-inducible gene transcription. J Biol Chem 2005, 280:21607-21611.

35. Leong H, Firestone GL, Bjeldanes LF: Cytostatic effects of 3,3'diindolylmethane in human endometrial cancer cells result from an estrogen receptor-mediated increase in transforming growth factor-alpha expression. Carcinogenesis 2001, 22:1809-1817.

36. Degner SC, Papoutsis AJ, Selmin O, Romagnolo DF: Targeting of aryl hydrocarbon receptor-mediated activation of cyclooxygenase-2 expression by the indole-3-carbinol metabolite 3,3'-diindolylmethane in breast cancer cells. J Nutr 2009, 139:26-32.

37. Kansra S, Yamagata S, Sneade L, Foster L, Ben-Jonathan N: Differential effects of estrogen receptor antagonists on pituitary lactotroph proliferation and prolactin release. Mol Cell Endocrinol 2005, 239:27-36.

38. Weinberg WC, Denning MF: P21Waf1 control of epithelial cell cycle and cell fate. Crit Rev Oral Biol Med 2002, 13:453-464.

39. Safe $S$, Wormke M: Inhibitory aryl hydrocarbon receptor-estrogen receptor alpha cross-talk and mechanisms of action. Chem Res Toxicol 2003, 16:807-816.

40. Ohtake F, Fujii-Kuriyama Y, Kawajiri K, Kato S: Cross-talk of dioxin and estrogen receptor signals through the ubiquitin system. J Steroid Biochem Mol Biol 2011, 127:102-107.

41. Tremblay A, Tremblay GB, Labrie F, Giguere V: Ligand-independent recruitment of SRC-1 to estrogen receptor beta through phosphorylation of activation function AF-1. Mol Cell 1999, 3:513-519.

42. Kato S, Endoh H, Masuhiro Y, Kitamoto T, Uchiyama S, Sasaki H, Masushige S, Gotoh Y, Nishida E, Kawashima H, Metzger D, Chambon P: Activation of the estrogen receptor through phosphorylation by mitogen-activated protein kinase. Science 1995, 270:1491-1494.

43. Endoh H, Maruyama K, Masuhiro Y, Kobayashi Y, Goto M, Tai H, Yanagisawa J, Metzger D, Hashimoto S, Kato S: Purification and identification of p68 RNA helicase acting as a transcriptional coactivator specific for the activation function 1 of human estrogen receptor alpha. Mol Cell Biol 1999, 19:5363-5372.

44. Lavinsky RM, Jepsen K, Heinzel T, Torchia J, Mullen TM, Schiff R, Del-Rio AL, Ricote M, Ngo S, Gemsch J, Hilsenbeck SG, Osborne CK, Glass CK, Rosenfeld MG, Rose DW: Diverse signaling pathways modulate nuclear receptor recruitment of N-CoR and SMRT complexes. Proc Natl Acad Sci U S A 1998, 95:2920-2925.

45. Masood S: Estrogen and progesterone receptors in cytology: a comprehensive review. Diagn Cytopathol 1992, 8:475-491.

doi:10.1186/1471-2407-14-524

Cite this article as: Marques et al.: Low levels of 3,3'-diindolylmethane activate estrogen receptor $a$ and induce proliferation of breast cancer cells in the absence of estradiol. BMC Cancer 2014 14:524.

\section{Submit your next manuscript to BioMed Central and take full advantage of:}

- Convenient online submission

- Thorough peer review

- No space constraints or color figure charges

- Immediate publication on acceptance

- Inclusion in PubMed, CAS, Scopus and Google Scholar

- Research which is freely available for redistribution

Submit your manuscript at www.biomedcentral.com/submit
Ciomed Central 